\title{
Low-temperature synthesis of condensed zinc and cobalt (II) phosphate solid solution with the given anion structure
}

\author{
N.M.Antraptseva, N.V.Solod, O.D.Kochkodan \\ National University of Life and Environmental Sciences of Ukraine, \\ 15 Geroev Oborony Str., 03041 Kyiv, Ukraine
}

Received June 18, 2018

\begin{abstract}
The anionic composition of heat treatment products of crystalline hydrates of the general formula $\mathrm{Zn}_{1-x} \mathrm{Co}_{x}\left(\mathrm{H}_{2} \mathrm{PO}_{4}\right)_{2} \cdot 2 \mathrm{H}_{2} \mathrm{O}(0<x<1.00)$ under isothermal conditions is determined. Quantitative dependences of the content of condensed phosphates with different anion structure (linear and cyclic) and phosphate acids, which released as intermediate products, on the temperature regime and roasting duration were established. The influence of cation nature is shown. The conditions of the formation and thermal stability of everyone linear condensed phosphates with $\bar{n}=2-8$ and the solid solution of cyclotetraphosfates of the composition $\mathrm{Zn}_{1-x} \mathrm{Co}_{x} \mathrm{P}_{4} \mathrm{O}_{12}(0<x<1.00)$ are concretized.
\end{abstract}

Keywords: condensed phosphates, anion structure, isothermal conditions, solid solution.

Определен анионный состав продуктов термообработки кристаллогидратов общей формулы $\mathrm{Zn}_{1-x} \mathrm{Co}_{x}\left(\mathrm{H}_{2} \mathrm{PO}_{4}\right)_{2} \cdot 2 \mathrm{H}_{2} \mathrm{O}(0<x<1.00)$ в изотермических условиях. Установлены количественные зависимости содержания конденсированных фосфатов с различным строением аниона (линейные и циклические) и фосфатных кислот, выделяющихся в качестве промежуточных продуктов, от температурного режима и продолжительности обжига. Показано влияние природы катиона. Конкретизированы условия образования и термической стабильности каждого из линейных конденсированных фосфатов с $\bar{n}=$ 2-8 и твердого раствора циклотетрафосфатов состава $\mathrm{Zn}_{1-x} \mathrm{Co}_{x} \mathrm{P}_{4} \mathrm{O}_{12}(0<x<1,00)$.

Низькотемпературний синтез твердого розчину конденсованих фосфатів цинку i кобальту(II) із заданою будовою аніона. Н.М.Антрапщева, Н.В.Солод, О.Д.Кочкодан.

Визначено аніонний склад продуктів термообробки кристалогідратів загальної формули $\mathrm{Zn}_{1-x} \mathrm{Co}_{x}\left(\mathrm{H}_{2} \mathrm{PO}_{4}\right)_{2} \cdot 2 \mathrm{H}_{2} \mathrm{O} \quad(0<x<1,00)$ в ізотермічних умовах. Встановлено кількісні залежності вмісту конденсованих фосфатів з різною будовою аніона (лінійною i циклічною) і фосфатних кислот, що виділяються як проміжні продукти, від температурного режиму і тривалості випалу. Показано вплив природи катіону. Конкретизовано умови утворення і термічної стабільності кожного з лінійних конденсованих фосфатів із $\bar{n}=2-8$ і твердого розчину циклотетрафосфатів складу $\mathrm{Zn}_{1-x} \mathrm{Co}_{x} \mathrm{P}_{4} \mathrm{O}_{12}(0<x<1,00)$.

\section{Introduction}

Solid solutions of divalent metals condensed phosphate with different anion structure (linear or cyclic) are widely used to develop new modern polyfunctional materials with adjustable properties and performance characteristics on their basis [1-4].

One of the methods of condensed phosphate obtaining is the reaction of mixtures of the initial reagents of various compositions at high temperatures $\left(900-1200^{\circ} \mathrm{C}\right.$ and above): oxide or carbonate of the appropriate metal with the ammonium dihydrogen phosphate $[1,5]$, or with the individual cyclotetraphosphates $[1,6]$. The main disadvantage of this method, as well as of all the high-temperature methods of synthesis, is its high-energy intensity. Much less energyintensive and rational synthesis method is a 
low-temperature heat treatment of the corresponding crystalline hydrates [3, 7, 8].

There are few works in the scientific literature on the synthesis of a solid solution of condensed phosphates of zinc and cobalt (II) by a heat treating of the hydrated monophosphates $[9,10]$. The attention of the authors [9] was mainly paid to a study of the mechanism of thermolysis of dihydrogen phosphate of $\mathrm{Zn}_{0.5} \mathrm{CO}_{0.5}\left(\mathrm{H}_{2} \mathrm{PO}_{4}\right)_{2} \cdot 2 \mathrm{H}_{2} \mathrm{O}$ composition in a dynamically heat treatment conditions. It is shown, in particular, that its dehydration is accompanied by the complex physicochemical and structural transformations with the formation of condensed phosphates and free phosphate acid. The formation of anhydrous cyclotetraphosphate is the result of their solid-phase interaction. The preparative data about the obtaining (in a dynamic mode as well) of the three solidsolution compositions of condensed phosphates of $\mathrm{Zn}-\mathrm{Co}(\mathrm{II})$ with the linear structure of anion, are shown in the work [10].

However, it is not possible to obtain condensed phosphates of this anionic structure under the conditions of dynamic heating. Thence, most of crystalline burning processes are performed within the isothermal process, maintaining them during a needed time at a given temperature.

For the practical realization of the synthesis of condensed phosphates of the particular anionic composition and properties by a dehydration of hydrated salts during the isothermal process, and a control of this process, one requires data on the dependence of the anionic composition of intermediate and final products of dehydration on the temperature and duration of burning, as well as on the effect of the nature of the cation on them. Information on heat treatment of a solid solution of general formula $\mathrm{Zn}_{1-x} \mathrm{Co}_{x}\left(\mathrm{H}_{2} \mathrm{PO}_{4}\right)_{2} \cdot 2 \mathrm{H}_{2} \mathrm{O}(0<x<1.00)$ within the isothermal process is absent in a scientific literature.

The aim of this article is to justify the conditions of a low-temperature synthesis of a solid solution of condensed phosphates of zinc and cobalt (II) with a specified anion structure by the heat treatment of crystalline hydrates of $\mathrm{Zn}_{1-x} \mathrm{Co}_{x}\left(\mathrm{H}_{2} \mathrm{PO}_{4}\right)_{2} \cdot 2 \mathrm{H}_{2} \mathrm{O}$ $(0<x<1.00)$ composition within isothermal process.

\section{Experimental procedure}

The solid solution of

$\mathrm{Zn}_{1-x} \mathrm{Co}_{x}\left(\mathrm{H}_{2} \mathrm{PO}_{4}\right)_{2} \cdot 2 \mathrm{H}_{2} \mathrm{O}(0<x<1.00)$ with different contents of zinc and cobalt (II) was obtained by reaction of phosphoric acid
(64.13 wt. $\left.\% \mathrm{P}_{2} \mathrm{O}_{5}\right)$, taken in excess of $160-$ $180 \%$, with a mechanical mixture of Zinc hydroxocarbonate (77.25 wt.\%. ZnO) and cobalt (68.32 wt.\%. CoO). The composition of the initial reagents was changing according to the predetermined molar ratio, similar to [9].

The main objects of our study were the dihydrogen phosphates of the composition $\mathrm{Zn}_{0.75} \mathrm{CO}_{0.25}\left(\mathrm{H}_{2} \mathrm{PO}_{4}\right)_{2} \cdot 2 \mathrm{H}_{2} \mathrm{O}$,

$\mathrm{Zn}_{0.5} \mathrm{CO}_{0.5}\left(\mathrm{H}_{2} \mathrm{PO}_{4}\right)_{2} \cdot 2 \mathrm{H}_{2} \mathrm{O}$

and $\mathrm{Zn}_{0.25} \mathrm{Co}_{0.75}\left(\mathrm{H}_{2} \mathrm{PO}_{4}\right)_{2} \cdot 2 \mathrm{H}_{2} \mathrm{O}$. To determine the influence of the nature of the cation, they analyzed the heat treatment products of dihydrogen phosphates with different contents of zinc and cobalt (II), which varied in the range 19.97-2.26 wt.\% $\mathrm{Zn}$ and 2.00-18.32 wt.\% Co.

The heat treatment was performed in air in the range of $100-350^{\circ} \mathrm{C}$ (temperature detection accuracy is within $\pm 5^{\circ} \mathrm{C}$ ), keeping the sample at a given temperature for 0.5 , $1.5,3.0,5.0$ and $7.0 \mathrm{~h}$.

Heat treatment products were identified using a complex of analytical methods: chemical, X-ray (diffractometer DRON-4-M connected to a computing complex based on IBM PC/AT 486 computer, $\mathrm{Fe} \mathrm{K}_{\alpha}$, NaCl internal standard), infrared spectroscopy at $20^{\circ} \mathrm{C}$ and $-190^{\circ} \mathrm{C}$ (Nexus- 470 spectrometer, 400-4000 sm-1 frequency range, $0.05 \%$ sample weight pressing into the $\mathrm{KBr}$ matrix). Determination of free phosphoric acid was carried out by the quinoline molybdate weighting method after its extraction with dried acetone. The anionic composition of the salt and acid components was analyzed by chromatography on paper with a quantitative evaluation of each of the condensed anions, as described in [11].

\section{Results and discussion}

The results of a thermoanalytic study of $\mathrm{Zn}_{0.5} \mathrm{CO}_{0.5}\left(\mathrm{H}_{2} \mathrm{PO}_{4}\right)_{2} \cdot 2 \mathrm{H}_{2} \mathrm{O}$ showed that the products of its heat treatment at $100^{\circ} \mathrm{C}$ for $0.5-3.0 \mathrm{~h}$ are a heterogeneous mixture of solids (salt component) and a liquid (acid component) containing a monophosphate anion. The formation of condensed phosphates under these conditions does not occur (Table 1).

The main component of the solid phase is anhydrous dihydrogen phosphate $\mathrm{Zn}_{0.5} \mathrm{CO}_{0.5}\left(\mathrm{H}_{2} \mathrm{PO}_{4}\right)_{2}$, the formation of which is clearly fixed on the X-ray patterns and IR spectra. The presence of the second component is indicated by diffraction reflections $\left(d_{\text {exp }} 1.23,0.76 \mathrm{~nm}\right)$, on the basis of which it 
Table 1. Anionic composition of condensed phosphates and the conditions of their synthesis by heat treatment $\mathrm{Zn}_{0.5} \mathrm{Co}_{0.5}\left(\mathrm{H}_{2} \mathrm{PO}_{4}\right)_{2} \cdot 2 \mathrm{H}_{2} \mathrm{O}$

\begin{tabular}{|c|c|c|c|c|c|c|c|c|c|c|c|c|}
\hline \multicolumn{2}{|c|}{$\begin{array}{l}\text { Heat treatment } \\
\text { conditions }\end{array}$} & \multirow{2}{*}{$\begin{array}{l}\mathrm{P}_{2} \mathrm{O}_{5} \\
\text { solt. } \\
\text { gen., } \\
\text { wt. } \%\end{array}$} & \multicolumn{10}{|c|}{ The phosphate content $\left(\mathrm{P}_{2} \mathrm{O}_{5}\right.$, wt.\% $)$ in the form } \\
\hline $\begin{array}{l}\text { Tempera- } \\
\text { ture, }{ }^{\circ} \mathrm{C}\end{array}$ & $\mid \begin{array}{c}\text { Dura- } \\
\text { tion, } h\end{array}$ & & mono- & di- & three- & tetra- & cyclotetra- & penta- & hexa- & hepta- & octa & higher \\
\hline \multirow[t]{5}{*}{100} & 0.5 & 49.17 & 49.2 & & & & & & & & & \\
\hline & 1.5 & 49.56 & 49.6 & & & & & & & & & \\
\hline & 3.0 & 48.52 & 48.5 & & & & & & & & & \\
\hline & 5.0 & 48.48 & 46.4 & 2.1 & & & & & & & & \\
\hline & 7.0 & 47.97 & 41.6 & 6.4 & & & & & & & & \\
\hline \multirow[t]{5}{*}{150} & 0.5 & 44.32 & 32.5 & 10.8 & 1.0 & & & & & & & \\
\hline & 1.5 & 44.29 & 21.0 & 21.5 & 1.8 & & & & & & & \\
\hline & 3.0 & 45.78 & 17.8 & 22.9 & 5.0 & 0.1 & & & & & & \\
\hline & 5.0 & 47.30 & 14.2 & 24.3 & 6.4 & 2.4 & & & & & & \\
\hline & 7.0 & 50.46 & 13.1 & 26.6 & 7.0 & 3.6 & 0.0 & 0.2 & & & & \\
\hline \multirow[t]{5}{*}{225} & 0.5 & 60.45 & 18.0 & 30.1 & 7.4 & 4.6 & 0.0 & 0.3 & & & & \\
\hline & 1.5 & 61.29 & 11.0 & 32.4 & 10.2 & 5.9 & 0.0 & 0.5 & 0.3 & 1.0 & & \\
\hline & 3.0 & 62.09 & 8.2 & 26.3 & 11.7 & 7.3 & 0.0 & 3.6 & 2.7 & 2.3 & & \\
\hline & 5.0 & 62.54 & 7.4 & 20.0 & 12.6 & 8.4 & 0.0 & 4.7 & 3.6 & 2.4 & 1.4 & 2.0 \\
\hline & 7.0 & 62.79 & 5.3 & 17.8 & 11.4 & 9.8 & 0.0 & 5.9 & 4.5 & 3.6 & 1.6 & 2.9 \\
\hline \multirow[t]{5}{*}{275} & 0.5 & 62.98 & 4.3 & 12.9 & 8.5 & 8.0 & 0.0 & 9.4 & 7.4 & 3.7 & 2.8 & 6.0 \\
\hline & 1.5 & 63.21 & 4.0 & 8.5 & 7.1 & 7.3 & $<0.1$ & 7.2 & 8.0 & 4.7 & 2.1 & 14.3 \\
\hline & 3.0 & 63.39 & 3.8 & 5.6 & 6.4 & 6.3 & 4.8 & 5.9 & 6.1 & 4.3 & 2.4 & 17.8 \\
\hline & 5.0 & 63.44 & 3.0 & 4.9 & 5.3 & 5.5 & 19.7 & 5.7 & 5.5 & 6.9 & 2.2 & 3.7 \\
\hline & 7.0 & 63.62 & 2.3 & 3.1 & 4.8 & 4.1 & 33.5 & 4.6 & 4.4 & 5.2 & 1.6 & \\
\hline \multirow[t]{3}{*}{350} & 0.5 & 64.47 & 1.2 & 2.0 & 2.2 & 2.3 & 56.8 & 0.0 & & & & \\
\hline & 1.5 & 64.61 & $0.6^{*}$ & \multirow[t]{2}{*}{0.0} & $1.7^{*}$ & \multirow[t]{2}{*}{0.0} & 62.3 & & & & & \\
\hline & 3.0 & 64.89 & $0.7^{*}$ & & $1.8^{*}$ & & 62.4 & & & & & \\
\hline
\end{tabular}

* Result of diphosphate hydrolysis during sample preparation to analysis.

was identified as the less protonated phosphate of the $\mathrm{Zn}_{0.5} \mathrm{CO}_{0.5} \mathrm{HPO}_{4} \cdot \mathrm{mH}_{2} \mathrm{O}$ composition (Fig. 1,a). Liquid phase - monophosphate acid - is fixed in the IR spectra by the absorption bands in the fixed area of $3600-2800 \mathrm{~cm}^{-1}$ and 2400-2200 $\mathrm{cm}^{-1}$, which is similar to the bands in the spectrum of the pure $\mathrm{H}_{3} \mathrm{PO}_{4}$, taken to identify its content in the products of the heat treatment (Fig. 1,b).

The processes of anion condensation in the salt component begin with burning of $\mathrm{Zn}_{0.5} \mathrm{Co}_{0.5} \mathrm{H}_{2} \mathrm{PO}_{4} \cdot 2 \mathrm{H}_{2} \mathrm{O}$ at $100^{\circ} \mathrm{C}$ for $5.0-$ $7.0 \mathrm{~h}\left(4.3-13.3 \%\right.$ of the total $\mathrm{P}_{2} \mathrm{O}_{5}$ is in the form of the diphosphate) and continue to delve further with the increase in temperature. Removal of two moles of water of crystallization $\left(150^{\circ} \mathrm{C}, 1.5 \mathrm{~h}\right)$ is accompanied by the increasing of diphosphate amounts (up to $48 \%$ of the total $\mathrm{P}_{2} \mathrm{O}_{5}$ ), and formation of condensed phosphate with linear structure with third degree of poly- condensation $(\bar{n})$. With an increase in the duration of heat treatment at $150^{\circ} \mathrm{C}$ up to 3-7 h, the removal of constitutional water is observed, and, as a result, a deeper anionic condensation with a formation of tri-, tetra - and penta phosphates $(\bar{n}=3-5)$ is taking place. The degree of conversion of monophosphate anion to polyphosphate is 61-73\%, respectively (Table 1). Under these burning conditions, anionic condensation is taking place also in the composition of the acid component, which is a mixture of mono- and diphosphate acid (Table 2). Similar changes in the composition of heat treatment products appear along with the destruction of the structure and the complete amorphization of the solid phase. Formation of X-ray amorphous condensed phosphates of linear structure with $\bar{n}=2-5$ in the composition of the salt component is recorded on chromatograms. In the IR spectra, their formation is indicated by the most 

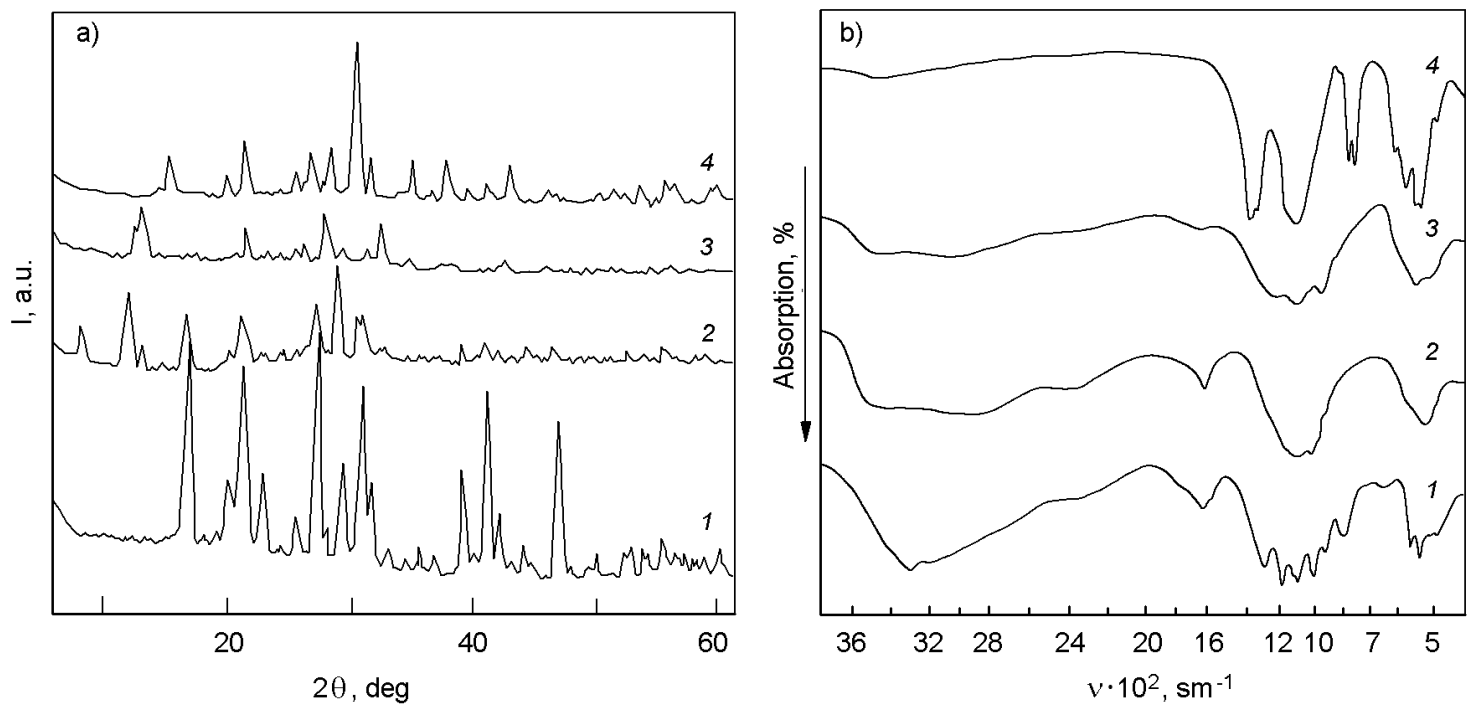

Fig. 1. X-ray diffraction patterns (a) and IR spectra (b) of $\mathrm{Zn}_{0.5} \mathrm{Co}_{0.5}\left(\mathrm{H}_{2} \mathrm{PO}_{4}\right)_{2} \cdot 2 \mathrm{H}_{2} \mathrm{O}(1)$ and products of its heat treatment for $0.5-0.3 \mathrm{~h}$ at $100(2), 225(3), 350^{\circ} \mathrm{C}(4)$.

Table 2. Anionic composition of free phosphate acids in heat treatment products of $\mathrm{Zn}_{0.5} \mathrm{Co}_{0.5}\left(\mathrm{H}_{2} \mathrm{PO}_{4}\right)_{2} \cdot 2 \mathrm{H}_{2} \mathrm{O}$

\begin{tabular}{|c|c|c|c|c|c|c|}
\hline \multicolumn{2}{|c|}{ Heat treatment conditions } & \multirow[t]{2}{*}{$\begin{array}{l}\text { Mass loss, } \\
\text { mole } \mathrm{H}_{2} \mathrm{O}\end{array}$} & \multirow[t]{2}{*}{$\begin{array}{l}\mathrm{P}_{2} \mathrm{O}_{5} \text { acid } \\
\text { gen, wt. } \% \text {. }\end{array}$} & \multicolumn{3}{|c|}{$\begin{array}{c}\text { Content of phosphate acids }\left(\mathrm{P}_{2} \mathrm{O}_{5} \text { acid., }\right. \\
\text { wt. } \%) \text { in the form }\end{array}$} \\
\hline$t,{ }^{\circ} \mathrm{C}$ & duration, $h$ & & & mono- & di- & three- \\
\hline \multirow[t]{5}{*}{100} & 0.5 & 0.45 & 2.72 & 2.7 & & \\
\hline & 1.5 & 0.71 & 3.40 & 3.4 & & \\
\hline & 3.0 & 0.84 & 4.97 & 5.0 & & \\
\hline & 5.0 & 0.97 & 5.47 & 5.5 & & \\
\hline & 7.0 & 1.11 & 6.61 & 6.6 & $<0.1$ & \\
\hline \multirow[t]{5}{*}{150} & 0.5 & 1.68 & 9.56 & 9.4 & 0.1 & \\
\hline & 1.5 & 2.03 & 10.01 & 8.6 & 1.4 & \\
\hline & 3.0 & 2.27 & 10.62 & 8.9 & 1.7 & \\
\hline & 5.0 & 2.38 & 9.71 & 7.4 & 2.3 & \\
\hline & 7.0 & 2.52 & 8.82 & 5.6 & 3.1 & $<0.1$ \\
\hline \multirow[t]{5}{*}{185} & 0.5 & 2.50 & 9.30 & 6.9 & 2.1 & 0.3 \\
\hline & 1.5 & 2.54 & 7.80 & 4.0 & 2.5 & 1.3 \\
\hline & 3.0 & 2.56 & 5.02 & 2.3 & 2.3 & 0.4 \\
\hline & 5.0 & 2.63 & 3.22 & 2.1 & 1.1 & \\
\hline & 7.0 & 2.65 & 2.02 & 2.0 & $<0.1$ & \\
\hline \multirow[t]{5}{*}{225} & 0.5 & 2.68 & 1.68 & 1.7 & & \\
\hline & 1.5 & 2.86 & 1.40 & 1.4 & & \\
\hline & 3.0 & 2.99 & 1.20 & 1.2 & & \\
\hline & 5.0 & 3.08 & 0.90 & 0.9 & & \\
\hline & 7.0 & 3.13 & 0.40 & 0.3 & & \\
\hline
\end{tabular}

intense absorption bands, characteristic for vibrations of di- and polyphosphate anions $\left(930 \mathrm{~cm}^{-1}-v_{a s}\right.$ POP, $1220 \mathrm{~cm}^{-1}-v_{a s}$ $\mathrm{PO}_{2}$ ). Moreover, the occurrence of $1220 \mathrm{~cm}^{-1}$ band allows to identify the linear condensed phosphates in the presence of mono- and diphosphates, which are not containing median group of OPO.

Formation of $\mathrm{Zn}_{0.5} \mathrm{CO}_{0.5}\left(\mathrm{H}_{2} \mathrm{PO}_{4}\right)_{2} \cdot 2 \mathrm{H}_{2} \mathrm{O}$ of the new crystal lattice is registered at 
$225^{\circ} \mathrm{C}$ in the burning products. The sample, which was kept at this temperature for $0.5 \mathrm{~h}$, is represented by the crystalline phase, and identified, according to [11-15], as a solid solution of protonated diphosphates with the $\mathrm{Zn}_{0.5} \mathrm{Co}_{0.5}\left(\mathrm{H}_{2} \mathrm{P}_{2} \mathrm{O}_{7}\right)$ composition and $\mathrm{Zn}_{0.5} \mathrm{CO}_{0.5}\left(\mathrm{H}_{2} \mathrm{P}_{2} \mathrm{O}_{7}\right)$ admixture (Fig. $1)$. The content of diphosphates in the composition of these heat treatment products is $49.8 \%$ of the total content of $\mathrm{P}_{2} \mathrm{O}_{5}$. Condensed phosphates with a linear anion structure with $\bar{n}=3-5$ are X-ray amorphous. Their number is $12.3 \mathrm{wt.} \%$ in recalculation on $\mathrm{P}_{2} \mathrm{O}_{5}$, and increases from 17.0 up to $39.7 \%$ wt., with an increase in the burning time from 1.5 up to $7.0 \mathrm{~h}$. The degree of polymerization of condensed phosphates produced during 5.0-7.0 h of burning, reaches 8 or more (Table 1 ). In the IR spectra the configuration of the absorption curves are characterized by a fairly well-defined individuality. They are characterized by the clear fixed peaks of $930 \mathrm{~cm}^{-1}$, $530 \mathrm{~cm}^{-1}$, splitting of the band at $1060 \mathrm{~cm}^{-1}$ (1055, $\left.1090 \mathrm{~cm}^{-1}\right)$, a new band with a maximum of $720 \mathrm{~cm}^{-1}$. The appearance of this band is considered to be an analytical sign of the presence of diphosphate, and the presence in the spectrum of a broad band with a maximum of $2900 \mathrm{~cm}^{-1}$ indicates the presence of a protonated anion, which is formed along with diphosphate (Fig. 1,b). The overall spectral pattern indicates the presence of a large number of amorphous products.

The maximum amount of diphosphate (32.4 wt.\%, which is $52.9 \%$ of the total $\mathrm{P}_{2} \mathrm{O}_{5}$ ) is formed during the burning of $\mathrm{Zn}_{0.5} \mathrm{CO}_{0.5}\left(\mathrm{H}_{2} \mathrm{PO}_{4}\right)_{2} \cdot 2 \mathrm{H}_{2} \mathrm{O}$ for $1.5 \mathrm{~h}$ at a temperature of $225^{\circ} \mathrm{C}$, and is decreased almost 2 times with its heat treatment for $7 \mathrm{~h}$ (Table 1). At the same time, in the condensed phosphate the maximum amounts of triphosphate $(12.6$ wt.\% for $5.0 \mathrm{~h})$ and tetraphosphate $(9.8$ wt. $\%$ for $7.0 \mathrm{~h})$ is formed. Similar changes in the composition of linear condensed phosphates are observed at $275^{\circ} \mathrm{C}$ : with increasing burning time, the amount of low-molecular weight phosphates with $\bar{n}=2-4$ decreases, high-molecular weight with $\bar{n}=5-8-$ increases. The maximum amount of pentaphosphate 9.4 wt. $\%$ is formed during the burning for $0.5 \mathrm{~h}$, hexaphosphate -8.0 wt. $\%-1.5 \mathrm{~h}$ (Table 1). Therefore, the composition of the salt component is complicated by an adequate decrease in the number of low-molecular weight phosphates, characterizing their direct participation in the solid-phase inter- actions with the formation of highly condensed phosphates with the linear structure of the anion.

The condensation of monophosphate acid begins at $150^{\circ} \mathrm{C}$, and finishes at $185^{\circ} \mathrm{C}(1.5-$ $3.0 \mathrm{~h}$ ) with a formation of polyphosphate acids with $\bar{n}$ not exceeding 3 (Table 2 ). A triphosphate is not observed in the composition of heat treatment products with an increase in the burning time up to $5.0 \mathrm{~h}$. Diphosphate acid is practically absent after the $7.0 \mathrm{~h}$ of burning time. Not only the qualitative but quantitative composition of free mono- and polyphosphate acids changes. The maximum number $(10.62$ wt. $\%)$ is registered in the products of heat treatment at a temperature of $150^{\circ} \mathrm{C}$ $(3 \mathrm{~h})$ is decreased with increasing duration of burning time and the temperature increase up to $225^{\circ} \mathrm{C}$ (Table 2). In a sample heated to $275^{\circ} \mathrm{C}$, free phosphate acids are practically absent. Their low content (primarily polyphosphate, as more active compared to $\mathrm{H}_{3} \mathrm{PO}_{4}$ ) indicates secondary interactions with low-molecular condensed phosphates.

Condensed phosphates of the most complex composition are formed at $275^{\circ} \mathrm{C}$. During the burning for $0.5-1.5 \mathrm{~h}$, they were identified as X-ray amorphous polymer phosphates with $\bar{n}=2-8$ and higher; the degree of conversion of monophosphate anion reaches 94-95\% (Table 1). After the heat treatment for $3.0-5.0 \mathrm{~h}$, the condensed phosphate with cyclic anion structure with $\bar{n}=4$ is present along with linear phosphates - cyclotetraphosphate. Its amount with an increase in the burning time duration up to $7 \mathrm{~h}$ reaches $54.6 \%$ of the total content of condensed phosphates. Formation of crystal lattice of cyclotetraphosphate is recorded on X-ray diffraction patterns by a number of the most intense diffraction reflections $\left(d_{\text {exp. }} 0.615, \quad 0.423,0.2992\right.$, $2.385 \mathrm{~nm}$ ). In IR spectra, one can observe an intense band with a maximum at $1330 \mathrm{~cm}^{-1}-v_{a s} \mathrm{PO}_{2}$ and doublet of 740$720 \mathrm{~cm}^{-1}-v_{a}$ POP, characteristic to the of vibrations of groups of condensed phosphates with cyclic structure of anion [14].

The heterophasic composition of the heat treatment products

of

$\mathrm{Zn}_{0.5} \mathrm{CO}_{0.5}\left(\mathrm{H}_{2} \mathrm{PO}_{4}\right)_{2} \cdot 2 \mathrm{H}_{2} \mathrm{O}$ is simplified with an increase in temperature up to $350^{\circ} \mathrm{C}$. Condensed phosphates with a linear anion structure with $\bar{n}=5-8$ after the $0.5 \mathrm{~h}$ of burning are absent. The content of monoand polyphosphates with $\bar{n}=2-4$ is decreased (Table 1). The amount of cyclotetra- 

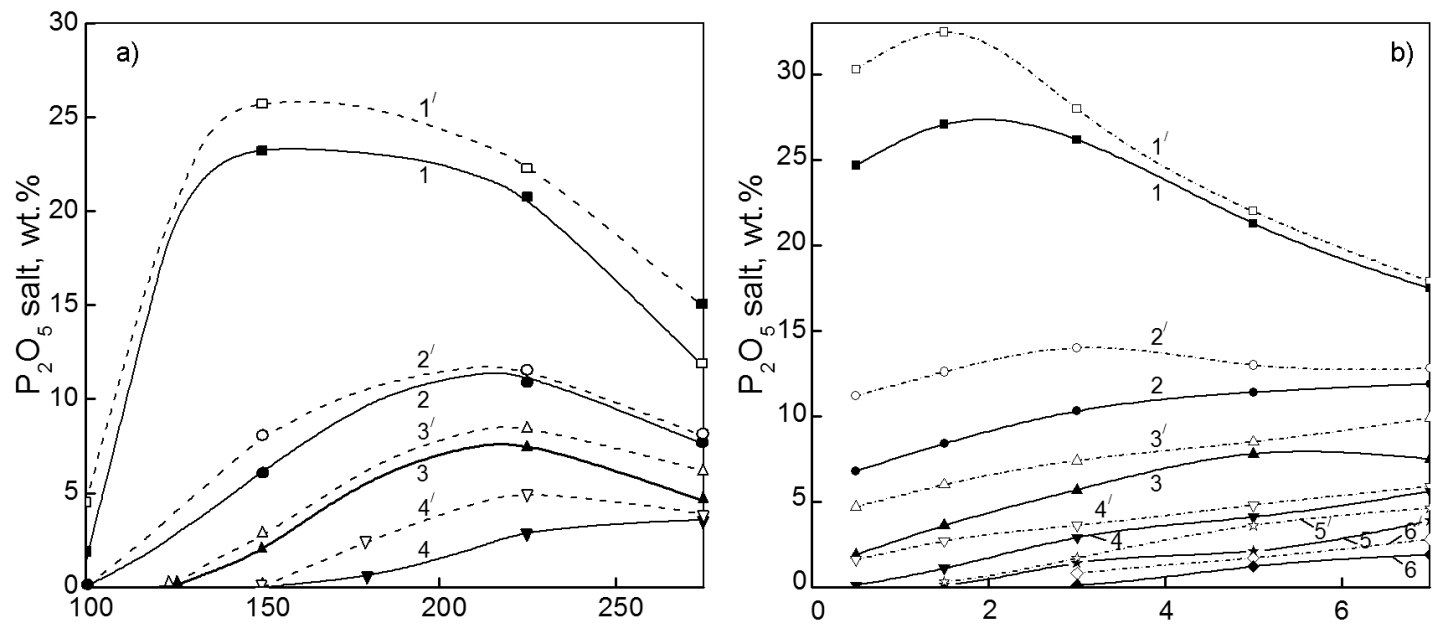

Fig. 2. The dependences of the condensed phosphates content in the products of heat treatment of $\mathrm{Zn}_{0.75} \mathrm{Co}_{0.25}\left(\mathrm{H}_{2} \mathrm{PO}_{4}\right)_{2} \cdot 2 \mathrm{H}_{2} \mathrm{O}$ (solid line) and $\mathrm{Zn}_{0.25} \mathrm{Co}_{0.75}\left(\mathrm{H}_{2} \mathrm{PO}_{4}\right)_{2} \cdot 2 \mathrm{H}_{2} \mathrm{O}$ (dashed line) on a - temperature (roasting for $5 \mathrm{~h}$ ), b - duration of burning (at $\left.225^{\circ} \mathrm{C}\right): 1,1-$ di-, $2,2^{\prime}-$ three-, $3,3^{\prime}-$ tetra-, $4,4^{\prime}-$ penta-, 5, 5' - hexa-, 6, 6'- heptaphosphate.

phosphate reaches $86.9 \%$ of the total $\mathrm{P}_{2} \mathrm{O}_{5}$. This process is accompanied by considerable structural rearrangements and physicochemical interactions, the result of which is the formation of a single condensed phosphate after the $1.5 \mathrm{~h}$ burning - cyclotetraphosphate with an anion ring structure. In the IR spectrum in skeletal anion vibrations area, one can observe clearly pronounced bands in the area characteristic for vibrations of condensed phosphates with an anion ring structure: $v_{a s} \mathrm{PO}_{2} \quad(1330,1285$, $\left.1230 \mathrm{~cm}^{-1}\right), v_{s} \mathrm{PO}_{2}\left(1170,1120,1110 \mathrm{~cm}^{-1}\right)$, $v_{a s}$ POP $\left(1055 \mathrm{~cm}^{-1}\right), v_{s}$ POP $\left(740-720 \mathrm{~cm}^{-1}\right)$ (Fig. 1,b). Its X-ray diffraction and known data for individual $\mathrm{Zn}_{2} \mathrm{P}_{4} \mathrm{O}_{12}$ and $\mathrm{Co}_{2} \mathrm{P}_{4} \mathrm{O}_{12}$ $[14,16]$ characterize them as compounds with the same type of structure that crystallize in the monoclinic syngony (space group $C 2 / c, Z=4$ ) with a formation of a solid solution of cyclotetraphosphates of the $\mathrm{ZnCoP}_{4} \mathrm{O}_{12}$ composition.

To study the effect on the nature of the cation on the synthesis conditions of condensed phosphates with a specific composition and structure of the anion, similar determinations were made for the heat treatment products of $\mathrm{Zn}_{0.75} \mathrm{Co}_{0.25}\left(\mathrm{H}_{2} \mathrm{PO}_{4}\right)_{2} \cdot 2 \mathrm{H}_{2} \mathrm{O}$ an $\mathrm{Zn}_{0.25} \mathrm{CO}_{0.75}\left(\mathrm{H}_{2} \mathrm{PO}_{4}\right)_{2} \cdot 2 \mathrm{H}_{2} \mathrm{O}$. The data obtained are presented in the form of dependences of the content of condensed phosphates (Fig. 2) and free phosphate acids (Fig. 3) on the temperature and duration of burning.

The analysis of the experimental data showed that the composition of the condensed phosphates, the conditions for their

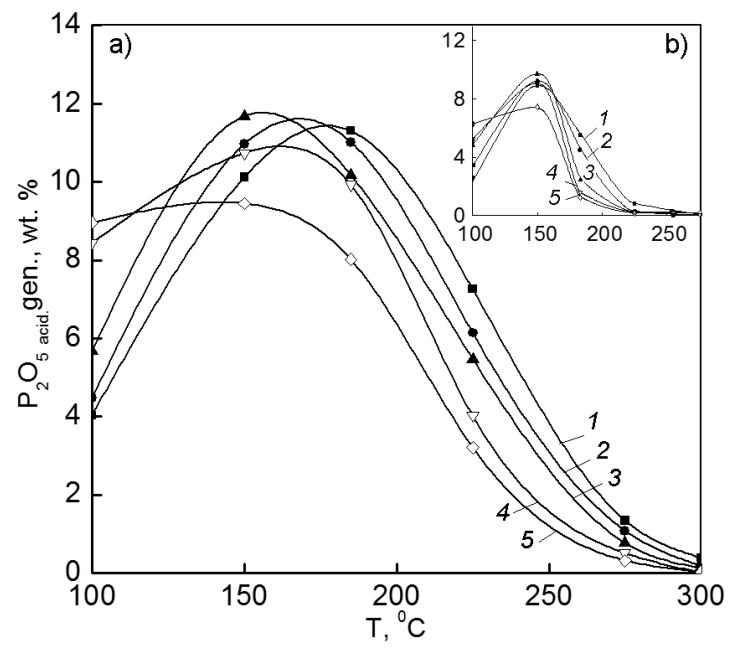

Fig. 3. The amount of free phosphate acids released during heat treatment of $\mathrm{Zn}_{0.75} \mathrm{Co}_{0.25}\left(\mathrm{H}_{2} \mathrm{PO}_{4}\right)_{2} \cdot 2 \mathrm{H}_{2} \mathrm{O}(\mathrm{a})$ and

$\mathrm{Zn}_{0.25} \mathrm{Co}_{0.75}\left(\mathrm{H}_{2} \mathrm{PO}_{4}\right)_{2} \cdot 2 \mathrm{H}_{2} \mathrm{O}$ (b): $1-0.5,2-$ $1.5,3-3.0,4-5.0$ and $5-7.0 \mathrm{~h}$ of burning.

formation and thermal stability, determined for the heat treatment products of $\mathrm{Zn}_{0.5} \mathrm{CO}_{0.5}\left(\mathrm{H}_{2} \mathrm{PO}_{4}\right)_{2} \cdot 2 \mathrm{H}_{2} \mathrm{O}$, sufficiently and correctly describe the thermal behavior of the solid solution of $\mathrm{Zn}_{1-x} \mathrm{Co}_{x}\left(\mathrm{H}_{2} \mathrm{PO}_{4}\right)_{2} \cdot 2 \mathrm{H}_{2} \mathrm{O}$ $(0<x<1.00)$ with different contents of zinc and cobalt (II).

Conditions for the synthesis of condensed phosphates with a specific structure of the anion (linear with $\bar{n}=2-8$ and higher, or cyclic with $\bar{n}=4$ ) depend on the content of zinc and cobalt (II) in them. For $\mathrm{Zn}_{1-x} \mathrm{Co}_{x}\left(\mathrm{H}_{2} \mathrm{PO}_{4}\right)_{2} \cdot 2 \mathrm{H}_{2} \mathrm{O}$ with a high content of cobalt (II) the temperature regime shifts 
at 10-20 degrees to higher temperatures. And the duration of burning time increases at $0.5-3.0 \mathrm{~h}$ at a given temperature.

The nature of the cation affects both the composition of the condensed phosphates and the quantitative ratios in it. With increasing content of Cobalt (II) in the composition of $\mathrm{Zn}_{1-x} \mathrm{Co}_{x}\left(\mathrm{H}_{2} \mathrm{PO}_{4}\right)_{2} \cdot 2 \mathrm{H}_{2} \mathrm{O}$, condensed phosphates are formed more intensively by 4-8 \% by weight. This difference attains a maximum value for a low-molecular polymer phosphate with $\bar{n}=2,3$, and is less noticeable in the formation of linear phosphates with $\bar{n}=\geq 5$. The established regularity is maintained for all the heat treatment conditions studied.

The amount of free phosphate acids in the composition of the heat treatment products is also different: the higher zinc content in $\mathrm{Zn}_{1-x} \mathrm{Co}_{x}\left(\mathrm{H}_{2} \mathrm{PO}_{4}\right)_{2} \cdot 2 \mathrm{H}_{2} \mathrm{O}$ is, the bigger amount of acid is formed in the burning products. This means, the share of their participation in the formation of highly condensed phosphates and the final product of heat treatment increases. It is a solid solution of cyclotetraphosphates of general formula $\left(\mathrm{Zn}_{1-x} \mathrm{Co}_{x}\right)_{2} \mathrm{P}_{4} \mathrm{O}_{12}(0<x<1.00)$ regardless of the composition of the initial crystalline hydrates.

The generalization of the obtained results makes it possible to trace the formation, accumulation, redistribution and participation of each of the polymeric phosphates and free phosphate acids in the complex physicochemical processes of the formation of condensed phosphates. This makes it possible to choose the optimal conditions for the low-temperature synthesis of the solid solutions of condensed zinc and cobalt (II) phosphates with a specified structure of the anion (linear with $\bar{n}=2-8$ and higher, or cyclic with $\bar{n}=4$ ).

\section{Conclusions}

By the heat treatment of the crystalline hydrates of $\mathrm{Zn}_{1-x} \mathrm{Co}_{x}\left(\mathrm{H}_{2} \mathrm{PO}_{4}\right)_{2} \cdot 2 \mathrm{H}_{2} \mathrm{O}(0<x<$ 1.00) composition within the isothermal process $\left(100-350^{\circ} \mathrm{C}, 0.5-7.0 \mathrm{~h}\right)$ one synthesized solid solutions of phosphates of zinc and cobalt (II) with specified anion structure (linear with $\bar{n}=2-8$, and cyclic with $\bar{n}=4)$. The optimal conditions for their low-temperature synthesis have been determined. The conditions of formation and thermal stability of each of the linear condensed phosphates with $\bar{n}=2-8$ and the solid solution of cyclotetraphosphates of the
$\mathrm{Zn}_{1-x} \mathrm{Co}_{x} \mathrm{P}_{4} \mathrm{O}_{12} \quad(0<x<1.00)$ composition are identified.

It is shown that the formation of condensed phosphates is accompanied by significant structural rearrangements, including the complete amorphization and the formation of structures of new crystalline phases - solid solutions of dihydrodi- and cyclotetra phosphates of zinc and cobalt (II).

Quantitative dependences of the condensed phosphates content with different structure of anion and phosphate acids, released as the intermediate products on the temperature regime and duration of burning of $\mathrm{Zn}_{1-x} \mathrm{CO}_{x}\left(\mathrm{H}_{2} \mathrm{PO}_{4}\right)_{2} \cdot 2 \mathrm{H}_{2} \mathrm{O} \quad(0<x<$ 1.00) have been established. The influence of cation nature on the conditions of lowtemperature synthesis and the quantitative composition of solid solutions of condensed zinc and cobalt (II) phosphates with different anion structure is shown.

\section{References}

1. T.Kanazawa, Inorganic Phosphate Materials, Elsevier, Amsterdam (1989).

2. L.Shchegrov, N.Antraptseva, V.Kopilevich, Phosphorus Sulfur, 51, 149 (1990).

3. L.Robertson, Etude de Pigments Thermochromes Autour du Cobalt II. Materiaux, Universite Sciences et Technologies, Bordeaux (2010).

4. Y.Chang, N.E.Shi, S.Zhao et al., ACS Appl. Mater. Inter., 34, 22534 (2016).

5. Z.A.Konstant, A.P.Dindune, Bivalent Metal Phosphates, Zinatne, Riga (1987) [in Russian].

6. M.Trojan, Thermochim.Acta., $\quad 143,131$ (1989).

7. N.Antraptseva, N.Tkachova, I.Ponomaryva, Pol.J.Chem., 80, 1623 (2006).

8. A.Takenara, M.Nakachima, Phos.Res.Bull., 21, 61 (2001).

9. N.Antraptseva, L.Shchegrov, Ukr.Him.Zh., 50, 1133 (1984).

10. UA Patent, 78492 (2013).

11. N.M.Antraptseva, N.V.Tkachova, J.Appl. Chem., 82, 1153 (2009).

12. M.T.Averbuch-Pouchot, J.Appl.Crystallogr., 7, 511 (1974).

13. N.M.Antraptseva, N.V.Solod, Functional Materials, 23, 657 (2016).

14. R.Y.Melnikova, E.V.Pechkovskiy, E.D.Dzuba et al., Atlas of IR Spectra of Phosphates: Condensed Phosphates, Nauka, Moscow (1985) [in Russian].

15. M.Harcharras, A.Ennaciri, F.Capitelli et al., Vib.Spectrosc., 33, 189 (2003).

16. JCPDS, Powder Diffraction Fill, Inorganic Phases, JCPDS International Centre for Diffraction Data, Swarthmere, USA, 1986, card No. 36-210, 21-1489. 